\title{
Urethral diverticulum: a potential hazard of penile clamp application for male urinary incontinence
}

\author{
Sidhartha Kalra, P Rao Srinivas, Ramanitharan Manikandan, \\ Lalgudi Narayanan Dorairajan
}

Department of Urology, Jawaharlal Institute of PostGraduate Medical Education and Research, Pondicherry, India

Correspondence to Dr Ramanitharan Manikandan, uromani77@gmail.com

Accepted 19 March 2015
CrossMark

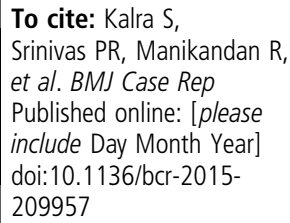

\section{DESCRIPTION}

Urinary incontinence is a common problem encountered after prostatectomy. After a trial of conservative management, men are generally left with a choice of surgery, drainage or absorbent devices, or a penile compression device. Artificial urinary sphincter is the current gold standard for management of post-prostatectomy incontinence with acceptable long-term success rates. However, in patients who are not fit to undergo another surgery or cannot afford these devices, especially in developing countries, penile compression devices come in handy. Use of these devices has been shown to cause a significant reduction in Incontinence Impact Questionnaire scores in different studies. ${ }^{1}$ However, these devices have the risk of complications such as pain, urethral erosion, obstruction and oedema, with long-term use. It is recommended to de-clamp these devices at a regular interval of $4 \mathrm{~h}^{2}$

We encountered a potential hazard from a penile compression device in the form of anterior urethral diverticulum. A 70-year-old man presented to our department with a history of painless progressively increasing swelling at the penoscrotal region for the past 2 years. He had been using a penile compression device for the past 6 years for postprostatectomy incontinence (figure 1). A micturating cystourethrogram showed an anterior urethral diverticulum (figure 2), which was confirmed on urethroscopy (figure 3). The possible aetiopathogenesis for the diverticulum, in this case, could be prolonged application of a penile clamp resulting in urinary stasis and increased urethral pressure. Increased urethral pressure can lead to infection and eventual suppuration of the periurethral glands. An alternative reason suggested for such an occurrence is necrosis of the urethral epithelium and subsequent urinary extravasation leading to a

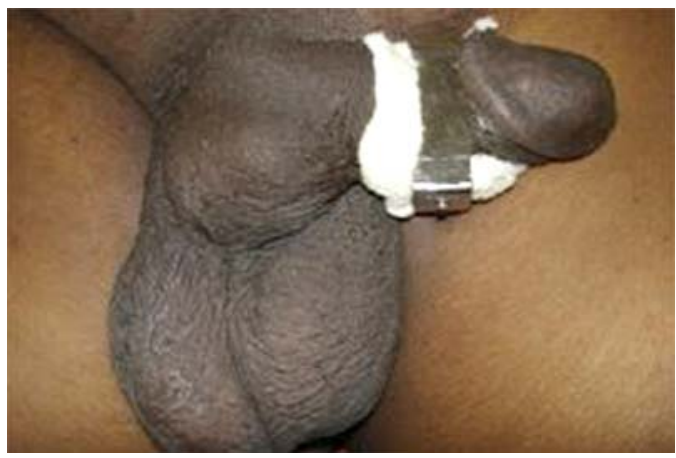

Figure 1 A ventral swelling at the penoscrotal region proximal to penile clamp application.

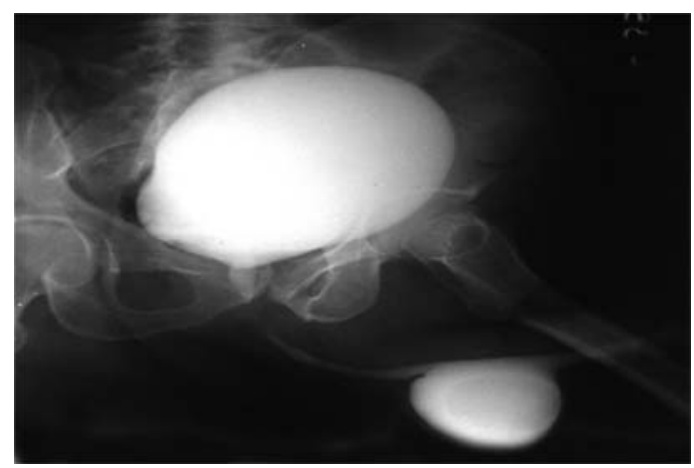

Figure 2 Voiding cystourethrogram (VCUG) showing anterior urethral diverticulum.

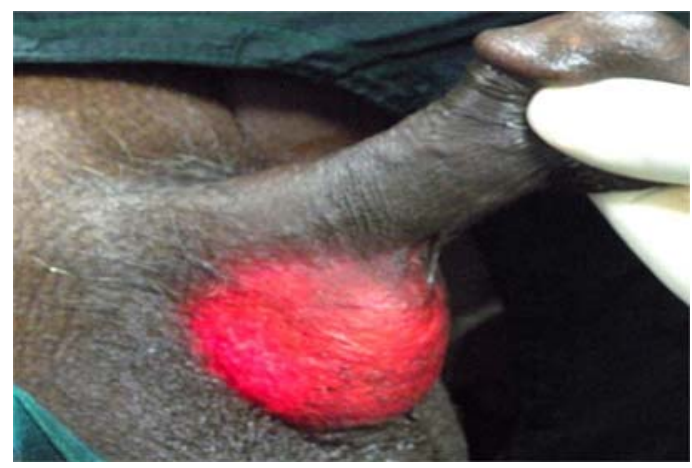

Figure 3 Brilliant transillumination in the diverticulum on urethroscopy.

periurethral abscess and diverticulum formation. Also, a history of instrumentation and previous catheterisation are risk factors for acquiring urethral diverticulum. ${ }^{3}$ The patient was managed with a diverticulectomy with urethral reconstruction and placement of a male urethral sling for incontinence.

\section{Learning points}

- Penile compression devices are a reasonable alternative to the present gold standard of artificial urinary sphincter for male urinary incontinence when surgical fitness or cost is an issue.

- However, these devices are associated with possible serious complications of urethral erosion, stricture or diverticulum.

- These devices should be used with extreme precaution with regular de-clamping at short intervals. 


\section{Images in...}

Contributors PRS was the resident in charge of the case and helped in data collection. SK reviewed the literature and gave structure to the manuscript. RM and LND were the expert reviewers for the manuscript.

Competing interests None declared.

Patient consent Obtained.

Provenance and peer review Not commissioned; externally peer reviewed.

\section{REFERENCES}

1 Barnard J, Westenberg AM. The penile clamp: medieval pain or makeshift gain? Neurourol Urodyn 2014;34:115-16.

2 Moore KN, Schieman S, Ackerman T, et al. Assessing comfort, safety, and patient satisfaction with three commonly used penile compression devices. Urology 2004;63:150-4.

3 Abreu S, Meller AE, Cury J. Giant stone in urethral diverticulum. Braz J Urol 2001;27:264-6.

Copyright 2015 BMJ Publishing Group. All rights reserved. For permission to reuse any of this content visit http://group.bmj.com/group/rights-licensing/permissions.

BMJ Case Report Fellows may re-use this article for personal use and teaching without any further permission.

Become a Fellow of BMJ Case Reports today and you can:

- Submit as many cases as you like

- Enjoy fast sympathetic peer review and rapid publication of accepted articles

- Access all the published articles

- Re-use any of the published material for personal use and teaching without further permission

For information on Institutional Fellowships contact consortiasales@bmjgroup.com

Visit casereports.bmj.com for more articles like this and to become a Fellow 